\author{
Katarzyna Biełuszko*
}

Gdynia Maritime Academy

\title{
CUSTOMER RATINGS AS A TOOL FOR THE INFORMATION ASYMMETRY REDUCTION IN THE HOSPITALITY MARKET
}

\begin{abstract}
One of the important stages of the buying process is seeking the information which should be valid, reliable and consistent with the current demand. Nowadays, in the information society, the source of this information is no longer primarily a service provider (eg. the hotel), but other consumers who have benefited from these services.The aim of this study is to make a comparative analysis of the methods for generating customer ratings of the hotels in the available online resources (online travel agencies and hotel e-intermediaries, hotel search engines, providers of travel reviews and social media). As a research tool, a critical review of the literature is used and exploration of online resources has been made. The study clearly shows that the customer rating systems are highly heterogeneous. Both the number and type of evaluation criteria, rating scale and definitions of reviewers are the factors which have significantly differentiated the analyzed systems. However, this heterogeneity and many other disadvantages such as the subjectivism of advisers, significant discrepancies between reviews et al., do not undermine these systems' usefulness in reducing information asymmetry in the hospitality market and in the decision-making process by the client.
\end{abstract}

Keywords: online reviews, e-intermediaries, quality systems, categorization of hotels

* E-mail adress: k.bieluszko@wpit.am.gdynia.pl. 


\section{Introduction}

One of the important stages of the buying process is seeking the information which should be valid, reliable and consistent with the current demand. Nowadays, especially in the information society, the source of this information is no longer primarily a service provider (eg. the hotel) but other consumers who have benefited from these services. Recently, reviews and ratings of customers have become so popular that their number should be estimated in millions. Thus, they contribute, to a large extent, to the reduction of market imperfection, or else, the asymmetry of information. In the case of hotel services, this is manifesting itself via the considerable advantage of the service provider: because of the service intangibility the customer cannot touch services, explore and see them prior to the arrival to hotel. So the client has to rely on the information of the owner. However, the potential customer can offset the advantage of using the opinions of others whose advantage in relation to the information from the owner is of greater credibility for them.

However, a multiplicity of opinions available on the websites makes it necessary to systematize the methods of collecting these reviews so as to indicate who forms them and according to which criteria and scale.

The aim of this study is to make a comparative analysis of the methods for generating customer ratings of the hotels in the available online resources. As a research tool a critical review of the literature has been used and the exploration of online resources has been made.

\section{Importance of customer ratings in the reduction of information asymmetry in the hospitality market}

The problem of information asymmetry in the hospitality market is associated largely with a significant gap between the possessed information about the hotel and its services and what the client actually buys and consumes. ${ }^{1}$ The solution to this problem would seems to be existing in many countries' categorization

M. Januszewska, E. Nawrocka, Funkcjonowanie przedsiębiorstw turystycznych $w$ warunkach niepewności i ryzyka, „Prace Naukowe Uniwersytetu Ekonomicznego we Wrocławiu” 2012, pp. 224-236. 
systems of hotel facilities (both obligatory and voluntary). In practice, however, it appears that these solutions are far imperfect due to the following reasons:

- lack of categorization systems in many countries,

- heterogeneous criteria and requirements for hotels dependent on country,

- ability to bypass the categorization process outside the official list,

- imperfect system of monitoring the process of categorization,

- customers' limited knowledge on the existence and the principles of categorization systems,

- limited access to the client categorization requirements in different countries (usually in the local language),

- only the quantitative requirements of categorization, lack of quality criteria,

- verification of the fulfilment solely of minimum requirements, lack of the information about the criteria above-standard,

- one-time assessment made by officials entitled to use the granted category indefinitely (the controls are rare, and the penalties when the criteria are not met symbolic).

As a result, many objects with the same number of stars in fact significantly differ from each other, both in the quality and standard of services, equipment, food, service, and often in the quantitative criteria - room/bathroom/bed etc. size. Due to the imperfections of the existing administrative systems of categorization and their insufficient role in reducing information asymmetry ${ }^{2}$ there have been introduced various systems of evaluation of hotels, which support consumer decisions. ${ }^{3}$ They include other informal methods of assessment of hotel facilities and services ${ }^{4}$, among them the following:

- introduction of service standards (for chain hotels) to ensure a consistent level of service in the objects belonging to the group of hotels,

J.A. Núñez-Serrano, J. Turrión, F.J. Velázquez, Are stars a good indicator of hotel quality? Assymetric information and regulatory heterogeneity in Spain, "Tourism Management" 2014, No. 42, pp. $77-87$.

3 J. Szumilak, Racjonalność zachowań nabywców ustug turystycznych w aspekcie gospodarowania informacja, „Folia Turistica” 2007, p. 7.

4 E.N. Torres, H. Adler, C. Behnke, Stars, diamonds, and other shiny things: The use of expert and consumer feedback in the hotel industry, "Journal of Hospitality and Tourism Management" 2014, No. 21, pp. 34-43. 
- certification of the hotel services - quality certificates in a variety of categories (spa \& wellness, business hotels, family-friendly etc.) guarantee the fulfilment of certain requirements necessary to obtain a certificate,

- conducting independent categorizations by e-intermediaries and online travel agencies,

- introduction of the customer ratings and reviews on the portals of e-intermediaries.

Nowadays, due to the growing importance of the Internet ${ }^{5}$ the scale and role of customers' feedback such as reviews on the web increases. ${ }^{6}$ The activity in this area is called eWOM (Electronic Word of Mouth). ${ }^{7}$ These opinions appear in many places on the Internet. Customers looking for an object often compare opinions from different sources in order to minimize the risk of making the wrong decision about choosing a hotel. ${ }^{8}$ The growing importance of the opinion on the Internet and their advantage over the official categorizations have been confirmed by studies of Ogut and Onur Tas..$^{9}$ They show that the increase in the value of customer ranking leads to the increase in the hotel's price, while the lack of similar relationship is observed with reference to the growth of official category. In addition, as confirmed by other researchers ${ }^{10}$, customer reviews have persuasive effects on customers' booking decisions. ${ }^{11}$ On the one hand,

$5 \quad$ K. Biełuszko, Opiniotwórcza rola mediów społecznościowych w ksztaltowaniu zachowań nabywczych klientów hoteli, in: Dynamika Przemian Rynku Turystycznego, ed. W. Banasik, Z. Kruczek, No. 1, WSTiJO, Warszawa 2014, pp. 213-229.

6 Z. Liu, S. Park, What makes a useful online review? Implication for travel product websites, “Tourism Management” 2015, No. 47, pp. 140-151.

7 A.S. Cantallops, F. Salvi, New consumer behavior: A review of research on eWOM and hotels, "International Journal of Hospitality Management" 2014, No. 36, pp. 41-51.

8 K.L. Xie, Z. Zhang, Z. Zhang, The business value of online consumer reviews and management response to hotel performance, "International Journal of Hospitality Management" 2014, No. 43, pp. 1-12.

9 H. Öğ̈̈, B.K. Onur Taş, The influence of internet customer reviews on the online sales and prices in hotel industry, "The Service Industries Journal” 2012, No. 32 (2), pp. 197-214.

10 Q. Ye, R. Law, B. Gu, The Impact of Online User Reviews on Hotel Room Sales, "International Journal of Hospitality Management” 2009, Vol. 28, No. 1, pp. 180-182; Q. Ye, R. Law, B. Gu, W. Chen, The Influence of User-generated Content on Traveler Behavior: An Empirical Investigation on the Effects of E-word-of-mouth to Hotel Online Bookings, "Computers in Human Behavior" 2011, Vol. 27, No. 2, pp. 634-639.

11 Q. Lu, Q. Ye, R. Law, Moderating Effects of Product Heterogeneity between Online Word-of-Mouth and Hotel Sales, "Journal of Electronic Commerce Research" 2012, No. 15 (1), pp. 1-12. 
the opinions and reviews help the client to perceive the quality and standard of the object, on the other hand, encourage the purchase. However, customer ratings conducted by e-intermediaries significantly differ from each other. This diversity of customer rating systems offered by different e-intermediaries is the cause for carrying out their detailed analysis.

\section{Research metodology}

The aim of this study is to make a comparative analysis of customer ratings of hotels in the available online resources. As a research tool a critical review of the literature has been used and the exploration of online resources has been made. The literature review and exploratory study help identify a group of online resources, where the hotel reviews are available. These are:

- online travel agencies and hotel e-intermediaries - 16 systems, ${ }^{12}$

- hotel search engines (comparing prices) - 4 searches, ${ }^{13}$

- providers of travel reviews -2 portals,${ }^{14}$

- social media - facebook. ${ }^{15}$

The study was conducted on March 3, 2015. The analysis of the above websites has included aspects relevant in view of suitability for users when making a choice of a hotel. Therefore, the following issues have been researched:

1. Does the analyzed website operate its own rating system for hotels or borrows it from other sources?

2. Who can issue opinions in the system?

3. Is there a classification of advisers due to their type of journey, travel company etc.?

12 On the basis of the literature on the subject and explored online resources there were selected, for the purpose of studying, the most popular and best promoted online systems, namely: hotele24.pl, staypoland.pl, hrs.com, booking.com, orbitz.com, hotele.pl, hotels.com, Expedia. com, lastminute.com, esky.pl, travelocity.com, agoda.pl, venere.com, easytobook.com, hotel opia. pl, hotel.info.

13 According to the above criteria, there were selected: trivago.pl, rezerwuje.pl, hotelcalculator.com, hotelscombined.com.

14 The most popular providers of travel reviews are: tripadvisor.com and holidacheck.com.

15 Among the social media, only Facebook has a separate tab for expressing an opinion on the fanpage. 
4. Are the hotels evaluated according to the descriptive opinion (review), point scale or another means of assessment (eg. recommendation)?

5. What elements are evaluated - the evaluation criteria?

\section{Systems of customer ratings of the hotel-results' analysis and discussion}

The variety of internet hotel reviews make customers confused when they are trying to analyze them and to obtain a reliable opinion. Therefore, it is extremely important to understand the rules of making and presenting reviews. At the outset, it should be noted that not all of the analyzed websites have the evaluation system for hotels, and many of them do not collect opinions on their own, but borrow them from other external sources. The most used source of customer opinions is Tripadvisor.com., the most influential travel portal (Figure 1).

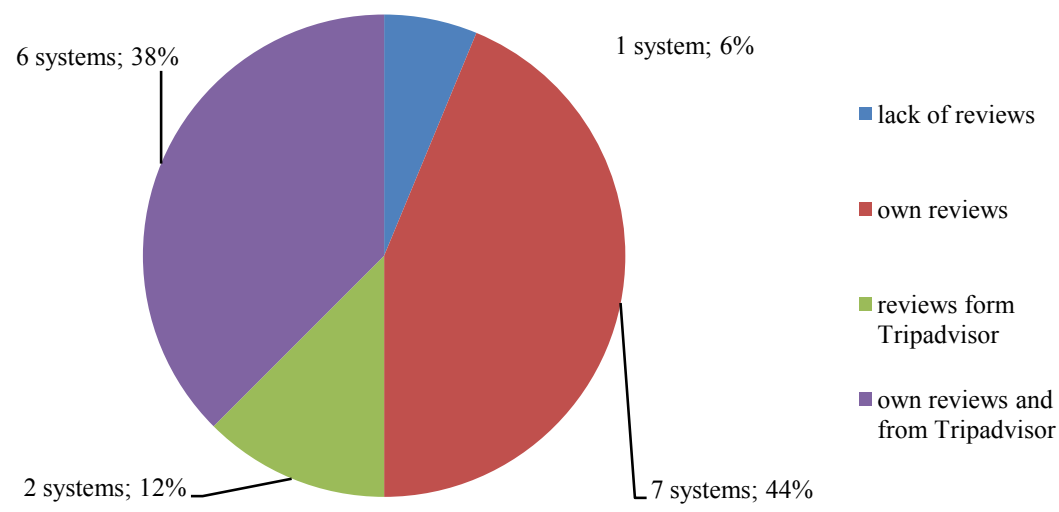

Fig. 1. Sources of hotel opinions in reservation systems

Source: own elaboration.

Of the 16 analysed reservation systems, seven run their own proprietary methodologies to assess hotels, one system does not offer customers' opinions about hotels, two systems collect their own opinions, but are relying also on Tripadvisor. The last two reservation systems show only opinions from Tripadvisor. In the case of hotel search engines, the situation is as follows: only one search engine gathers opinions from customers, and on this basis it makes hotel rating. The remaining three, due to the fact of presenting hotels available on different reservation 
systems, they direct for opinions of these systems. One exception is Trivago.pl which, on the basis of external opinions, creates a self-rating of hotels tRI. ${ }^{16}$ The third type of the website which offer hotel reviews are the opinion leaders portals (provider of travel reviews), i.e. Tripadvisor.com and holidaycheck.com. In both cases, the aim of these websites is presenting the opinions about hotels (and other companies in the industry, as well as tourist destinations). The last surveyed source of reviews for clients is the social networking site Facebook, where users can express their opinions of the hotel on its fanpage.

One of the factors that strongly determine the reliability of the reviews presented on the surveyed websites is information about the author. In this context two aspects - who can give opinions in systems and what was the purpose of stay in the hotel - have been examined. Almost all analyzed systems that collect reviews about hotels (except esky.pl) offer a possibility to issue an opinion only by those who actually made a reservation in the system and stayed in the hotel. Thus, this increases the reliability of presented reviews and opinions. Similarly, hotel search engines referring to the opinion in the reservation systems are based on the assessment of real-life experiences of hotel guests, as opposed to Tripadvisor, Holidaycheck.com and Facebook where anyone can place a review and rate a hotel regardless of whether s/he actually has been or not to this place.

The presented opinions are more or less useful for people who read them, depending on who issues them and for what purpose s/he visited the hotel because it allows the reader to assess to which extent their needs can be met. Therefore, it is important to classify reviewers into clearly defined categories. Among the 22 analyzed sources of reviews (hotele24.pl does not collect opinions, so was excluded from further study and analysis), only six do not classify reviewers: Facebook, two hotel search engines and three reservation systems. On the other websites, the person providing the opinion is asked to give the purpose or the nature of his/her stay. Both the way of defining the nature of stay and the number of categories of reviewers, remain for various e-intermediaries very heterogeneous, i.e. range from 3 to 9 categories. The most common types of stay of reviewers are: business purposes or family trip, travel with friends, alone or with a partner (Figure 2). Yet, there are also systems that apply the criterion of age (travellers and their children) or the specific purpose of travel, like shopping or spa.

16 tRI - trivago Rating Index - takes available rating sources from across the web and uses an algorithm to aggregate them, providing a dependable and impartial score (www.trivago.com). 


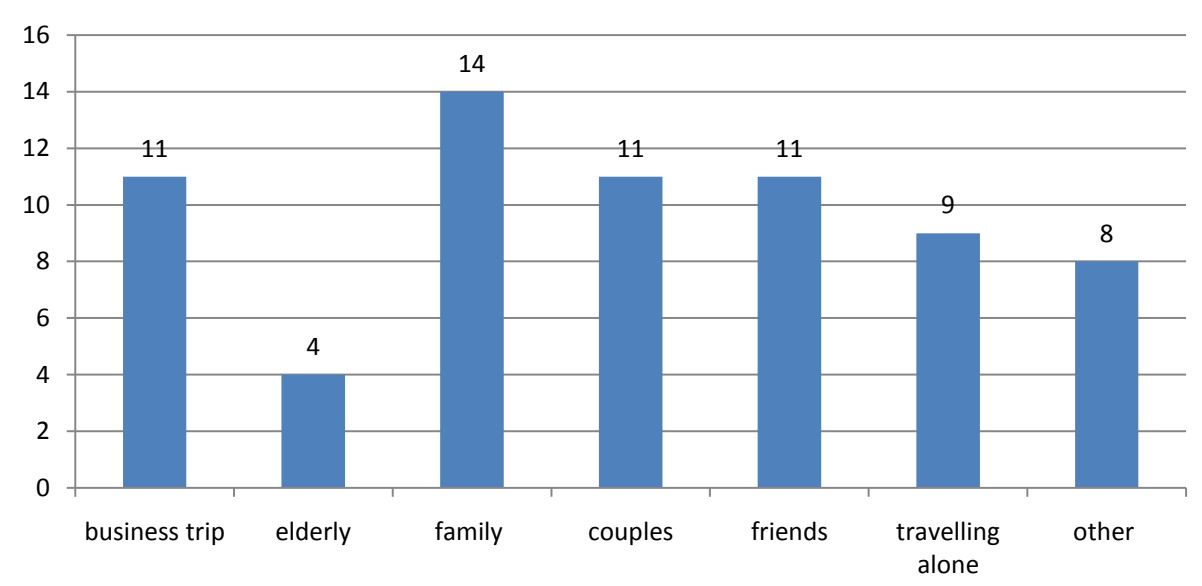

the number of e-intermediaries using given criterion of classification of reviewers

Fig. 2. Classification of reviewers on the analyzed websites Source: own elaboration.

People who look for reviews of the hotel, usually, in the first place pay attention to the rating of the object, then also often change the order of display of objects according to this criterion, and only then they go to the reviews (both positive and negative). The analysed systems in the vast majority (18 of 22) show both a descriptive assessment (opinion) and point scale (in range 1-5, 1-6 or 1-10), and the three systems also present the percentage of customers who are satisfied with their stay and/or give a recommendation for object. Only in the case of hotelscombined.pl there appears point evaluation without description, and in the case of Trivago it is necessary to visit the reservation system to read the reviews.

The final issue analysed within the framework of the research is the criteria of ratings. The smallest number of criteria occurs on travelocity.com (only 3) and Expedia.com (only 4), and the three systems carry out the rating based on five criteria. As many as 8 systems calculate their ratings based on 6 components, two systems - based on 7 criteria, the most comprehensive ranking is provided by staypoland.pl ( 9 criteria) and hrs.com (14 criteria). In toto, all websites report 24 criteria among which the most frequently repeated are: staff/service (16 systems), cleanliness (14 times), localization (12 systems), breakfast/meal (11 times), value for money ( 9 times) and 6 times the comfort and silence. Other criteria appear occasionally in one, two or three systems (Figure 3). 


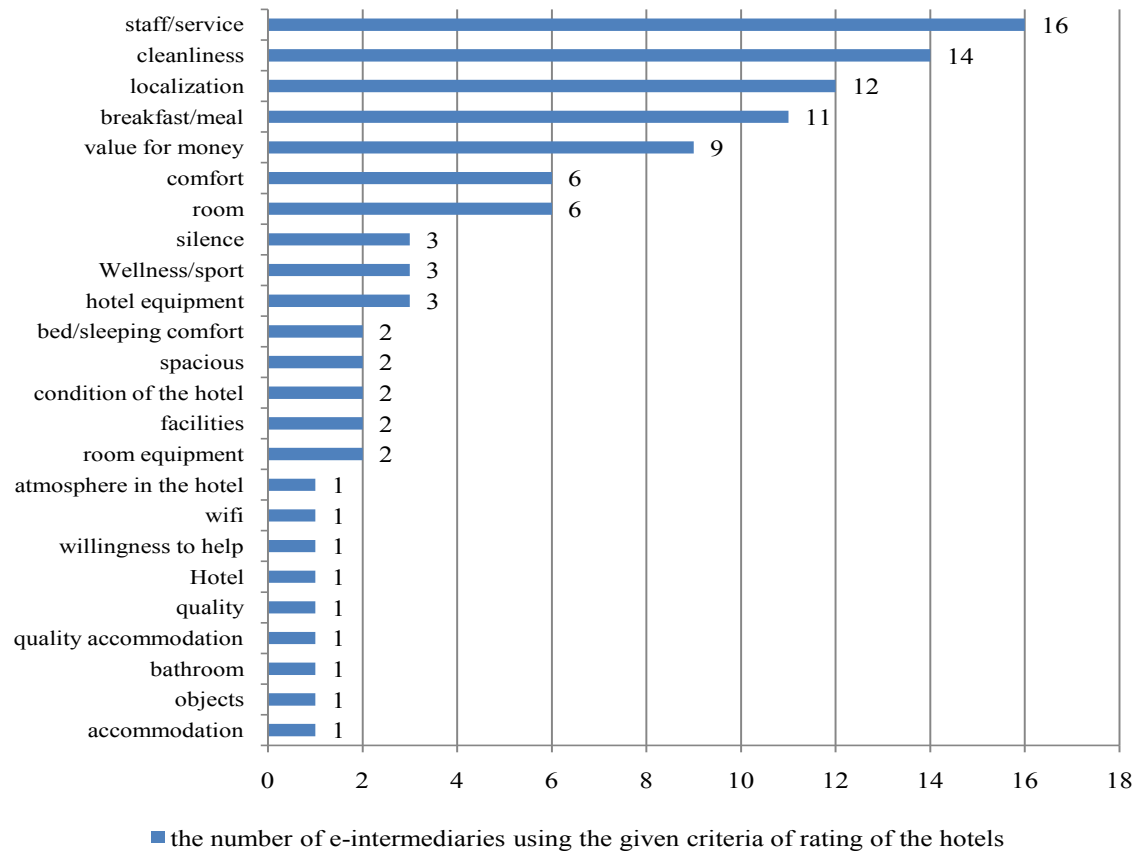

Fig. 3. Criteria of rating of the hotels in the analysed systems

Source: own elaboration.

\section{Discussion, limitations and directions for further research}

Due to the imperfection of the existing systems of categorization, the hotels are taking a number of actions to reduce the uncertainty for potential customers and encourage them to choose their object. For this purpose they enter into a variety of evaluation systems: certificates, marketing programs, chain standards as well as they submit themselves to the verification of their guests. All of these actions reduce information asymmetry in the market because they enrich customers knowledge about objects of interest. The customer rating (based on reviews) is the only one in which the client is actively involved in the process of evaluating, hence its popularity is so high. The number of reviews for some hotels issued by customers is over several thousand. However, this method, despite the many advantages, has also disadvantages as confirmed by studies (Table 1). 
Table 1 .

Advantages and disadvantages of customer ratings of hotels in e-intermediaries

\begin{tabular}{|c|c|}
\hline Advantages & Disadvantages \\
\hline $\begin{array}{l}\text { - made on the basis of assessments of hotel } \\
\text { guests } \\
\text { - take into account the quality criteria (eg. } \\
\text { service, atmosphere, friendliness) } \\
\text { - take into account the criterion of value } \\
\text { for money } \\
\text { - classify the reviewers due to the purpose } \\
\text { of the stay (eg. family, business) } \\
\text { - assessments are continuous, and not only } \\
\text { during the inspection }\end{array}$ & $\begin{aligned} & \text { - } \text { subjectivism of the reviewers } \\
& \text { - } \text { ignore the diversity of needs } \\
& \text { and expectations of the advisers } \\
& \text { - } \text { significant differences between guests' } \\
& \text { evaluations (the same hotel for different } \\
& \text { people can be unique or unsatisfactory) } \\
& \text { - in some systems lack of verification } \\
& \text { of the reliability of opinions } \\
& \text { - enigmatically sounding assessment criteria } \\
& \text { (eg. quality, room) }\end{aligned}$ \\
\hline
\end{tabular}

Source: based on own studies and K. Biełuszko, R. Kubicki, A. Pawlicz, Wpływ kategoryzacji na rozwój elektronicznych kanałów dystrybucji na przykładzie rynku ustug hotelarskich w Unii Europejskiej, „e-mentor” 2015, No. 1 (58), pp. 75-80.

The obtained results show that the assessments made by customers are based on similar criteria but are not consistent with the requirements of official categorization, primarily due to their qualitative nature. Surely, this is what makes them so useful for those who read them. Analysing the criteria in the tested systems of assessment, it should be noted that in the study by Suzuki based on the analysis of 350 thousand reviews, the frequently appearing words are isolated thus setting the desirable criteria of assessment. Among them there are: location, facilities, service, meal, room, lobby, bath, amenity, network, beverage, bed and parking lot have been found. Also, Levy et al. ${ }^{17}$ has conducted the analysis of the reviews, only negative though (one-star opinions). Among the characteristics most often subjected to criticism are: front desk staff, bathroom, cleanliness, noise, check-in, parking, restaurants, billing, room size and housekeeping staff. To a large extent, these coincide with the criteria used in the assessment of hotels in the present study and can thus be considered so as to meet the demand for information from the people who read them. The only objections are that in the analysed ratings of e-intermediaries silence rarely appears as a criterion (just three systems) although it is relatively important for customers. There is also the total lack in surveyed ratings of the criteria such as bathroom and parking.

17 S.E. Levy, W. Duan, S. Boo, An analysis of one-star online reviews and responses in the Washington, DC, Lodging Market, "Cornell Hospitality Quarterly" 2013, No. 54 (1), pp. 49-63. 
One of the main advantages of the analysed systems of assessment is the presence in as many as nine of them the criterion of value for money important especially for those looking for hotels providing the highest standard and quality at an acceptable level of price.

In addition, an important value for readers is the ability to select categories of the reviewers whose opinions are important for a potential client. In some systems, there exist a possibility of viewing opinions of other hotels from the given adviser allowing the reader to choose those advisers whose expectations and needs are similar. The main limitation of the research is that it does not verify the analysed variables based on examples of opinions, and only examines the formal rules of their issuing instead. Certainly, it could be interesting to examine if and how the assessments of individual objects in a variety of reservation systems differ, which of these systems are the most popular (the largest number of reviews), and whether there is a relationship between the number of opinions about the object and its administrative category.

\section{Summary}

The study clearly shows that the customer rating systems are highly heterogeneous. Both the number and type of evaluation criteria, rating scale and definitions of reviewers are the factors which have significantly differentiated the analysed systems. However, this heterogeneity and many other disadvantages such as the subjectivism of advisers, significant discrepancies between reviews et al. do not undermine their usefulness in reducing information asymmetry in the hospitality market and in the decision-making process by the client.

\section{References}

Biełuszko K., Opiniotwórcza rola mediów społecznościowych w ksztaltowaniu zachowań nabywczych klientów hoteli, in: Dynamika Przemian Rynku Turystycznego, eds. W. Banasik, Z. Kruczek, No. 1, WSTiJO, Warszawa 2014.

Biełuszko K., Kubicki R., Pawlicz, A., Wplyw kategoryzacji na rozwój elektronicznych kanałów dystrybucji na przykladzie rynku ustug hotelarskich $w$ Unii Europejskiej, „e-mentor” 2015, No. 1 (58).

Cantallops A.S., Salvi F., New consumer behavior: A review of research on eWOM and hotels, "International Journal of Hospitality Management" 2014, No. 36. 
Januszewska M., Nawrocka E., Funkcjonowanie przedsiębiorstw turystycznych w warunkach niepewności i ryzyka, Prace Naukowe Uniwersytetu Ekonomicznego we Wrocławiu No. 259, Wrocław 2012.

Levy S.E., Duan W., Boo S., An analysis of one-star online reviews and responses in the Washington, DC, Lodging Market, "Cornell Hospitality Quarterly" 2013, No. 54 (1).

Liu Z., Park, S., What makes a useful online review? Implication for travel product websites, "Tourism Management" 2015, No. 47.

Lu Q., Ye Q., Law R., Moderating Effects of Product Heterogeneity between Online Word-of-Mouth and Hotel Sales, "Journal of Electronic Commerce Research" 2014, No. 15 (1).

Núñez-Serrano J.A., Turrión J., Velázquez F.J., Are stars a good indicator of hotel quality? Assymetric information and regulatory heterogeneity in Spain, "Tourism Management" 2014, No. 42.

Öğ̈̈t H., Onur Taş B.K., The influence of internet customer reviews on the online sales and prices in hotel industry, "The Service Industries Journal” 2012, No. 32 (2).

Suzuki Y., Classifying Hotel Reviews into Criteria for Review Summarization, 24th International Conference on Computational Linguistics 2012.

Szumilak J., Racjonalność zachowań nabywców ustug turystycznych $w$ aspekcie gospodarowania informacja, ,Folia Turistica” 2007.

Torres E.N., Adler H., Behnke C., Stars, diamonds, and other shiny things: The use of expert and consumer feedback in the hotel industry, "Journal of Hospitality and Tourism Management" 2014, No. 21.

Xie K.L., Zhang Z., Zhang Z., The business value of online consumer reviews and management response to hotel performance, "International Journal of Hospitality Management" 2014, No. 43.

Ye Q., Law R., Gu B., The Impact of Online User Reviews on Hotel Room Sales, "International Journal of Hospitality Management" 2009, Vol. 28, No. 1.

Ye Q., Law R., Gu B., Chen W., The Influence of User-generated Content on Traveler Behavior: An Empirical Investigation on the Effects of E-word-of-mouth to Hotel Online Bookings, "Computers in Human Behavior" 2011, Vol. 27, No. 2.

\section{OPINIE KLIENTÓW JAKO NARZĘDZIE REDUKCJI ASYMETRII INFORMACJI NA RYNKU HOTELARSKIM}

\section{Streszczenie}

Jednym z istotnych etapów procesu zakupowego, także usług hotelarskich, jest poszukiwanie informacji, które powinny być aktualne, wiarygodne i zgodne z zapotrzebowaniem. Współcześnie, tj. w dobie społeczeństwa informacyjnego, źródłem tych informacji nie jest już głównie dostawca usługi, czyli hotel, ale inne osoby, które z owych usług korzystały. Jednak mnogość opinii dostępnych w Internecie sprawia, 
że konieczne staje się usystematyzowanie metod zbierania tych opinii, tak, aby jasne było kto jest wystawia oraz według jakich kryteriów i skali.

Celem badań było dokonanie analizy porównawczej metod generowania opinii o hotelach w dostępnych zasobach internetowych. Jako narzędzie badawcze zastosowano krytyczny przegląd literatury oraz eksplorację zasobów internetowych.

Przeprowadzone badania pokazują wyraźnie, iż systemy wystawiania ocen przez klientów są niejednorodne. Zarówno liczba i rodzaj kryteriów oceny, skala oceny, jak i definicje opiniodawców są czynnikami znacznie różnicującymi analizowane systemy. Wśród nich znajdują się takie, w których ocenie poddawane są 3 parametry oraz takie, w których klient ma ocenić aż 14 cech. Owa niejednorodność oraz wiele innych wad wskazanych w niniejszym artykule, takich jak subiektywizm opiniodawców, znaczne rozbieżności między ocenami i in., nie podważa jednak ich przydatności w redukcji asymetrii informacji na rynku usług hotelarskich oraz w procesie podejmowania decyzji przez klienta hotelu.

Słowa kluczowe: opinie klientów, recenzje klientów, e-pośrednicy, systemy oceny jakości, kategoryzacja hoteli 